\title{
PLANKTON STUDIES IN A MANGROVE ENVIRONMENT. V. SALINITY TOLERANCES OF SOME PLANKTONIC CRUSTACEANS
}

(Received 13/8/1968)

\author{
J. Tundisi \& T. M. TundisI
}

Instituto Oceanográfico da Universidade de São Paulo

\begin{abstract}
The salinity tolerances of adult females of some relevant species of planktonic copepods were studies in a mangrove region of the estuarine type, at $25^{\circ}$ south latitude. Results showed a wide range in the salinity tolerances for the adult females of all the species studied. Based on these experiments the following order of salinity tolerance can be proposed:

Pseudodiaptomus acutus $>$ Euterpina acutifrons $>$ Acartia lilljeborgi $>$ Oithona ovalis $>$ Centropages furcatus $>$ Temora stylifera.

A mechanism for the maintenance of Pseudodiaptomus acutus at certain regions of the area studied is proposed, based on experimental and field results.

It seems probable, thus that salinity is an important factor in the distribution of some members of the zooplankton in this region.
\end{abstract}

SYNOPSIS

\section{INTRODUCTION}

The studies of salinity tolerances of estuarine and coastal planktonic organisms can bring some useful information to support further investigations on their distribution, life history and responses to environmental changes.

Salinity variations are a significant factor in determining the spatial distribution and seasonal succession of estuarine plankton, and also the extent to which organisms from adjacent coastal waters can enter the estuaries (KетсhUM, 1954; Jeffries, 1962 a, b; Gunter, 1961).

Investigations on the effect of changes in salinity in the survival of planktonic animals, and non planktonic free-living copepods, were carried out by some authors in temperate waters - MARSHALL et al. (1935), Barnes (1953), Ranade (1957), Barnett (1959) and LANCE $(1962 ; 1964)$ but little information has been provided in this respect for tropical waters. The data available are restricted to some species of marine zooplankton off the Caribbean and South Atlantic - HopPER (1960) or on distribution studies based on fixed samples and salinity determination - VANNUCCI (1957), BJöRNBERG (1963), Teixeira et al. $(1962,1965)$.

Publ. n.o 257 do Inst. Ocean. da USP.
The investigations reported here were carried out in a mangrove region of the estuarine type at $25^{\circ}$ south latitude, Brazil (see sketch).

Published data and recent results demonstrated that the zooplankton was composed mainly by copepods and their larval stages - Teixeira \& Kutner, (1962), TeixeIra et al. (1965, 1967 in preparation). Also in view of the data available it was suggested that the changes and the gradient in salinity might be an important factor, affecting distribution of different planktonic species in this region. Therefore an attempt has been made to compare the extent to which some of the most important members of the zooplankton can withstand changes in salinity and how this ability checks with the distribution of some of the species studied.

\section{MATERIAL AND METHODS}

The plankton for the experimental procedure was collected with conic nets (pore size 189 to $250 \mu$ ) in the channel of the mangrove region, or in coastal waters. After the capture the animals were brought immediately to the laboratory and quickly sorted out in subdued light. Experiments commenced within approximately one hour after sampling. 


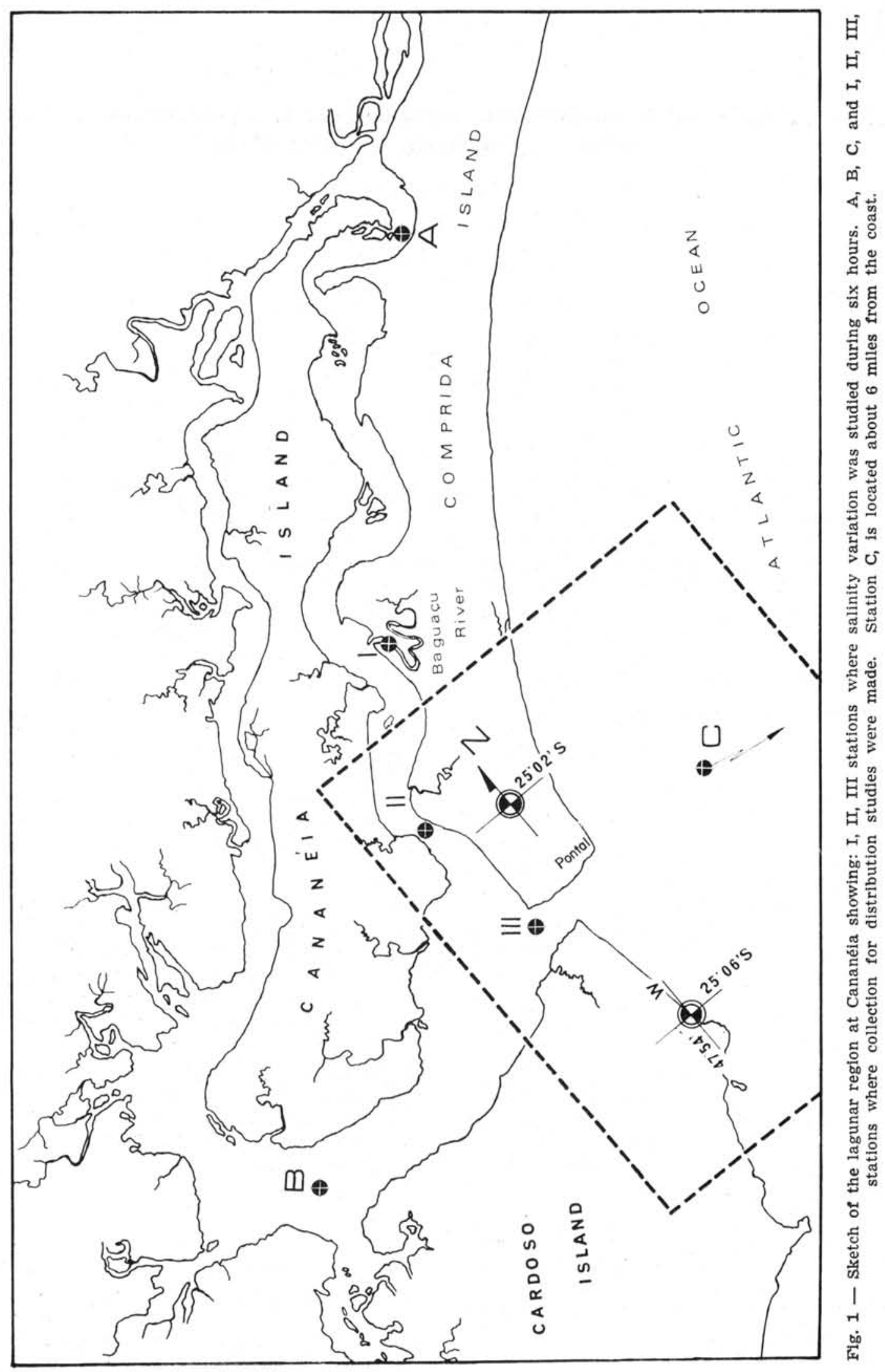


Previous work in coastal and shelf waters BJöRNBERG (1963) and in the mangrove region TeIXeIRA et al. (1965) provided a background for the study on distribution. Sampling was made with an 8 litre bottle at this time in inshore waters. Since the zooplankton in these waters is composed mainly by small copepods, this method was adequated, once selectivity for these smaller forms, can be neglected (HANSEN \& ANDERson, 1962).

\section{Species Studied}

Six species of copepods were studied: Pseudodiaptomus acutus, Euterpina acutifrons, Temora stylifera, Oithona ovalis, Centropages furcatus, Acartia lilljeborgi. In addition a decapod larva Zoea) which occur in abundance during some times of the year was also studied.

All experiments were performed mainly with adult females of the species studied.

\section{Experimental}

1 - Water of salinity of $30^{\circ} \%$ was considered as $100 \%$ sea-water. Previous results (TeixeIra et al., 1965; Kato, 1966) demonstrated that sea-water of this salinity is more frequent in the entrance of the estuary than water of higher salinity. Therefore the extent to which this water was diluted was considered to be as the gradient that the zooplankton has to support in inshore waters. Recent surveys (TundisI \& Matsumura, 1967, unpublished results) confirmed this point.

The sea water was filtered through Whatmann $\mathrm{n} .^{\circ} 1$ filter paper to remove larger suspended material and zooplankton.

Dilution was done by adding distilled water to this filtered sea water. Table I shows the range of dilution used, as well as the corresponding salinities. The value of $100 \%$ corresponds to the smaller dilution (i.e. sea water of $30 \%$ salinity). Thus $5 \%$ corresponds to the highest dilution (i.e. sea water + distilided water of salinity $1.6 \%$ ).

2 - An average of fifty animals of the same species was placed in beckers with $200 \mathrm{ml}$ of the experimental water.

According to KINNE (1963) the temperature can shift, broader or narrow the tolerances to salinity. Consideration of a single factor in isolation from all others could therefore provide evidence of limited significance. Thus all the experiments were conducted in the dark, at a temperature close to that recorded in the field at the time of sampling (within $\pm 1^{\circ} \mathrm{C}$ ) in a G.E. incubator. No food was added nor the experimental vessels had any supply of oxygen.

Some tests were done to check a possible influence of the use of distilled water instead of fresh water. Multiple runs with single species using distilled water and fresh water were set up and gave no significant differences. Thus only dilution with distilled water was used throughout.

Controls were set up with animals of the same species of the experiment in $200 \mathrm{ml}$ of filtered water, collected at the time the tow was made. The sur. vival of the animals in the control experiments was good. The results for the controls were compared with the results for experimental salinities, and percentage survival calculated according to LANCE (1962, 1964). The salinities which caused the death of one half of the original number were considered to be as lethal salinities $(L D=50)$. Results are based on duplicate experiments for all species studied. No significant differences were found in simultaneous runs.

Experiments lasted for six hours since the main purpose was to compare the survival during half a tidal cycle.

\section{3 - Acclimatization Experiments}

These short-term experiments were carried out with adult females of Acartia lilljeborgi. Since this species penetrates into inshore waters it can be useful to compare its ability to acclimatize to lower salinities during six hours. Thus the survival of animals which had been transferred directly to diluted water was compared to the survival of those gradually transferred to lower dilutions.

For each dilution the same batch of animals was left during half an hour and transferred subsequently to the lower dilution.

\section{4-Salinity Variation}

The variation of salinity at three stations studied was measured every half hour at surface and at $5 \mathrm{~m}$, by sampling with a Nansen bottle during six hours. All salinity determinations were carried out by titration according to the method of HARVEY (1955) with an accuracy of 0.05 .

TABLE I - Salinities and correspondent dilutions used for experiments

\begin{tabular}{|c|c|c|c|c|c|c|c|c|c|c|c|}
\hline $\begin{array}{l}\text { Dilution } \\
(\%)\end{array}$ & 100 & 90 & 80 & 70 & 60 & 50 & 40 & 30 & 20 & 10 & 5 \\
\hline $\begin{array}{c}\text { Salinity } \\
(\% / 00)\end{array}$ & 30.0 & 27.0 & 23.8 & 20.9 & 17.8 & 15.1 & 13.2 & 8.8 & 6.3 & 3.1 & 1.6 \\
\hline
\end{tabular}




\section{RESULTS}

\section{a - General}

For each species studied survival in $100 \%$ sea water and in the range of dilutions imposed at $25 \pm$ $1^{\circ} \mathrm{C}$ varied widely.

\section{Pseudodiaptomus acutus}

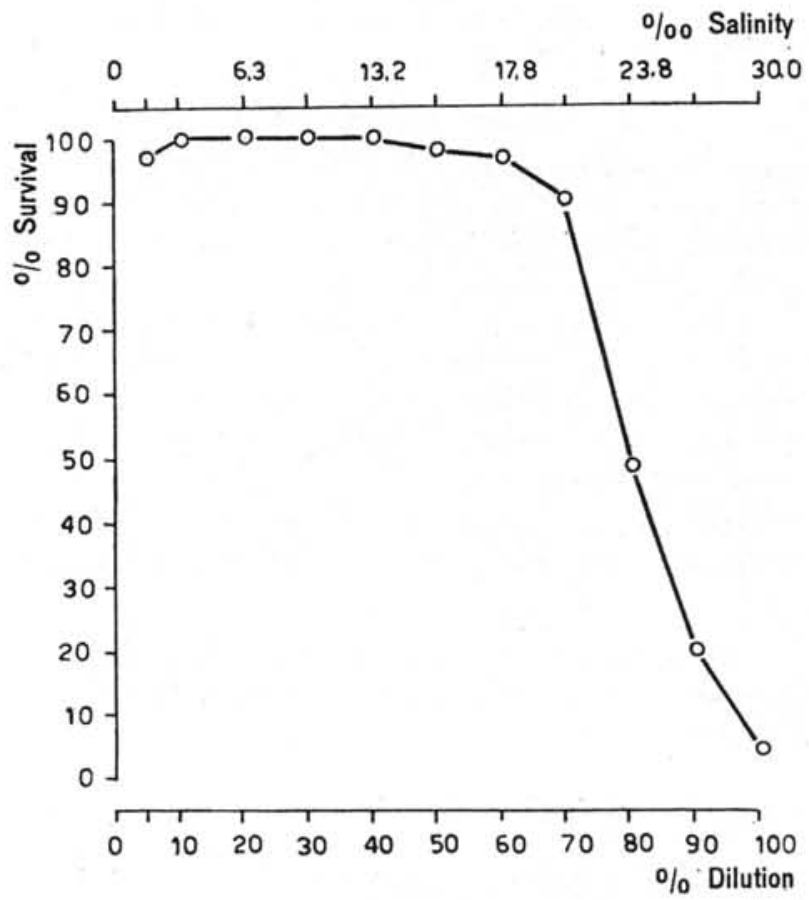

\section{Euterpina acutifrons}

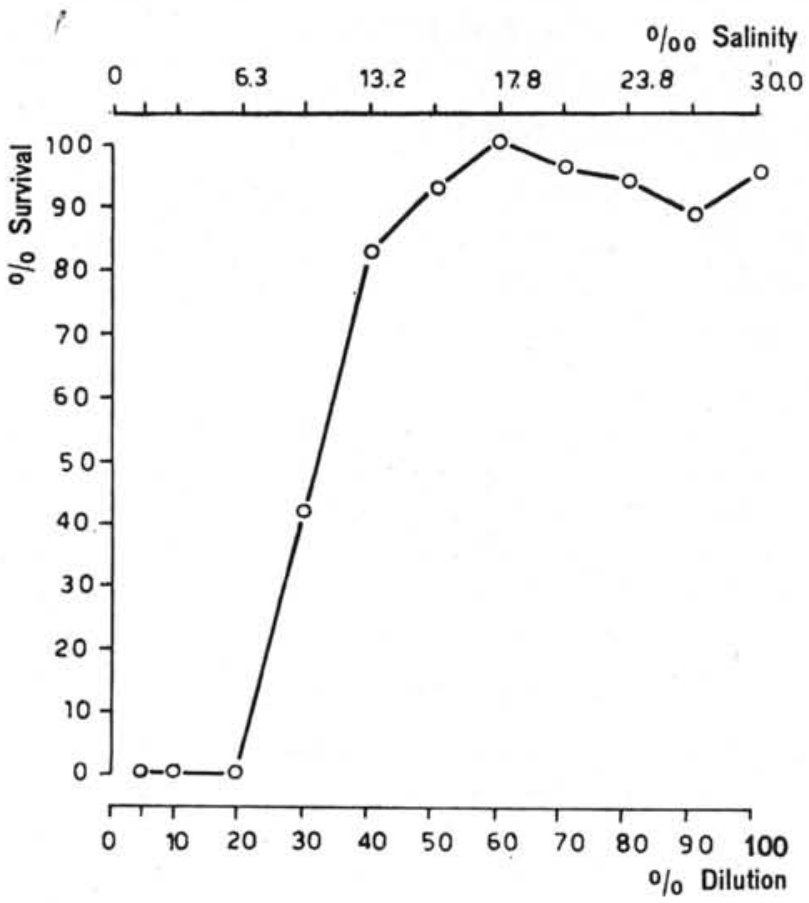

Fig. 2 - Salinity tolerances of Pseudodiaptomus acutus and Euterpina acutifrons.
Pseudodiaptomus acutus showed a high degree of tolerance to a wide range of dilutions. Only at the upper limit of the range $(100-80 \%$ sea water $)$ this species has its lethal salinity.

For all the other species a marked decrease in survival at salinities at the lower end of the range was observed.

Lethal salinity for Euterpina acutifrons was the corresponding to $30 \%$ dilution (salinity $8.8 \%$ ).

Oithona ovalis has its lethal salinities corresponding to $20 \%$ dilution (i.e. 6.3 salinity), and $90-$ $100 \%$ (salinity $26.0 \%-30.0 \%$ ).

Acartia lilljeborgi can withstand dilutions from $100-40 \%$; no mortality occurred at this corresponding salinities. Lethal salinity was the corresponding to $30 \%$ dilution.

Centropages furcatus is less tolerant to higher dilutions. For this species lethal salinity was at the corresponding to $40 \%$ dilution (i.e. salinity $13.2 \%$ ).

Temora stylifera has its lethal salinity at $50 \%$ dilution. However for this species mortality occurred from the dilution of $90 \%$ downwards (salinity $26.0^{\circ} / 00$ ).

These results thus show that Acartia lilljeborgi can withstand higher dilutions than Centropages furcatus and Temora stylifera.

Decapod larvae showed a high degree of tolerance, no mortality occurring in the whole range that it was submited.

Variation in the salinity tolerances for each species studied is demonstrated at Figures 2 to 5 .

Decapod larvae (Zoea)

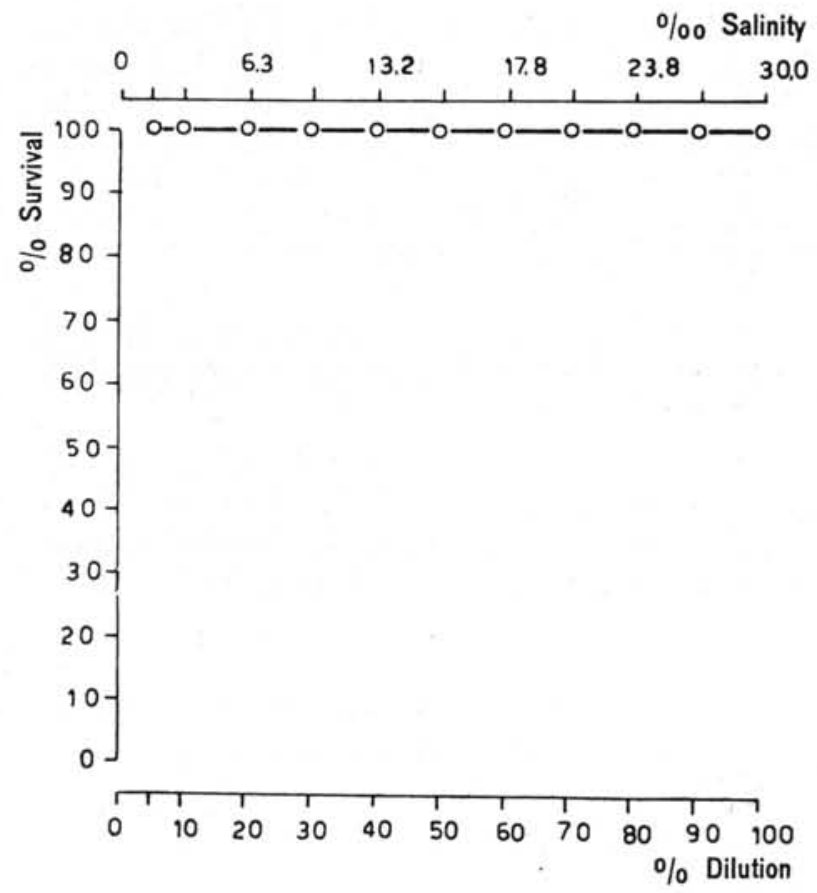

Fig. 3 - Salinity tolerance of a decapod larvae (Zoea). 


\section{Oithona ovalis}

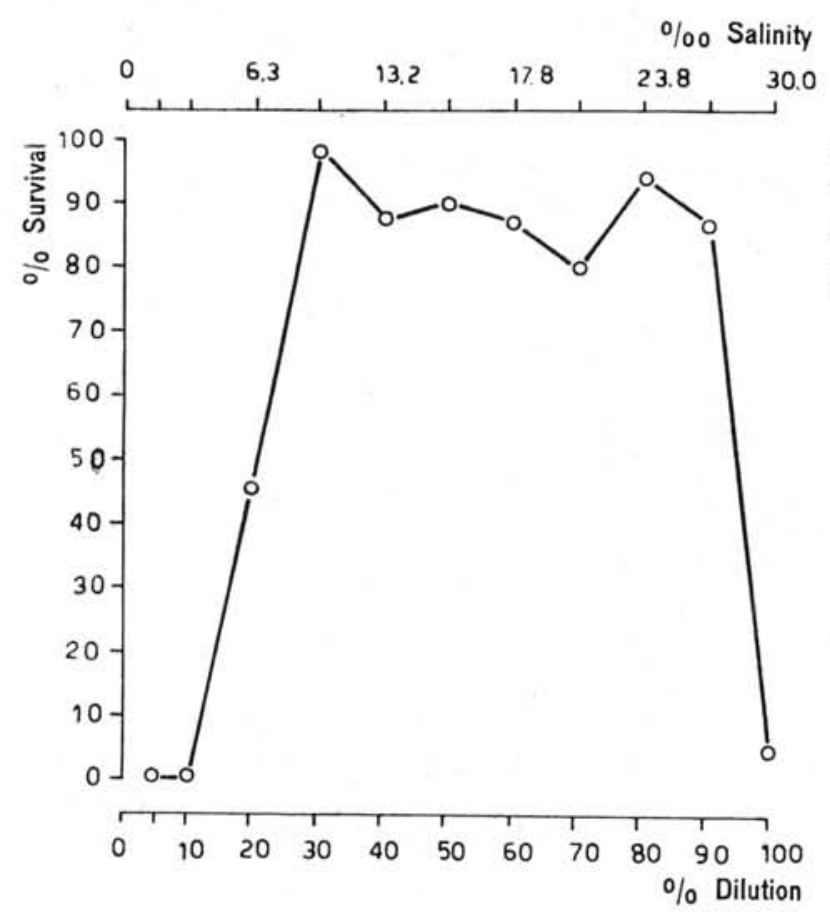

Fig. 4-Sallnity tolerance of Oithona ovalis.

\section{b - Salinity Acclimatization}

When $A$. lilljeborgi is acclimatized to higher dilutions the range of lethal salinities decrease from $30 \%-0 \%$ dilution to $10 \%-0 \%$ dilution. Figure 6 shows the differences in survival for acclimatized and non acclimatized Acartia.

Table II summarizes the range of lethal salinities at $25 \pm 1{ }^{\circ} \mathrm{C}$ for the adult females of all species studied and also for the decapod larvae.

Table III shows the range of salinity variation during six hours at the three stations studied at surface and at $5 \mathrm{~m}$ depth.

Based on these results and earlier data the following order of salinity tolerances can be proposed for the adults females of the species studied:

Pseudodiaptomus acutus $>$ Euterpina acutifrons $>$ $>$ Acartia lilljeborgi $>$ Oithona ovalis $>$ Centropages furcatus > Temora stylifera.
Temora stylifera

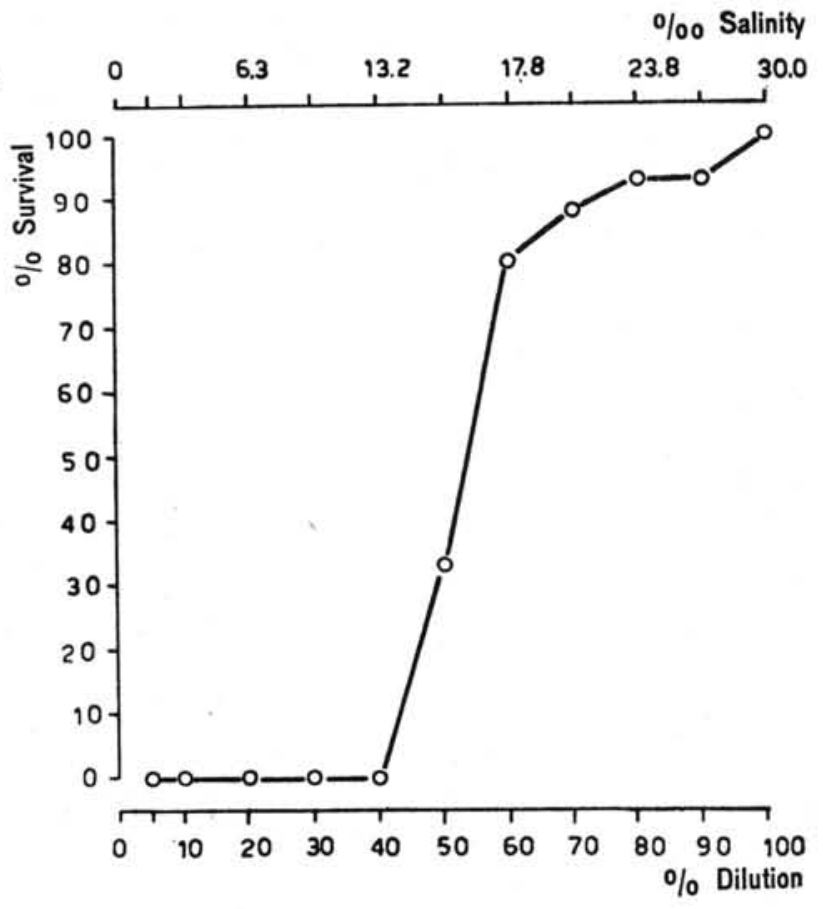

\section{Centropages furcatus}

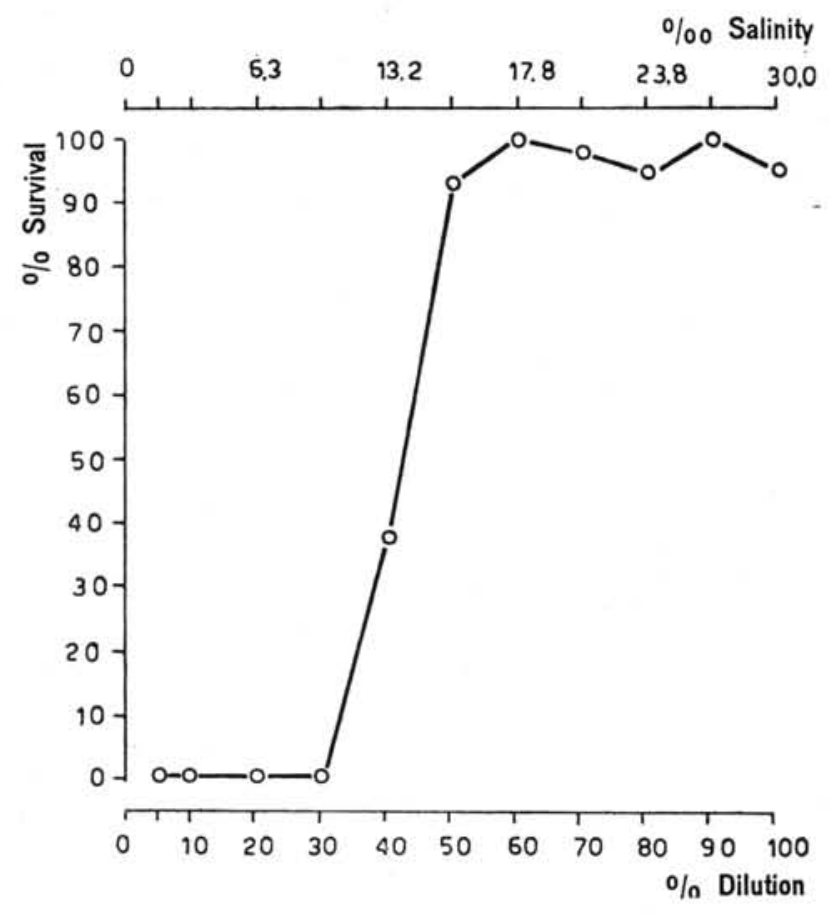

Fig. 5 - Salinity tolerances of Temora stylifera and Centropages furcatus. 
Acartia liljeborgi

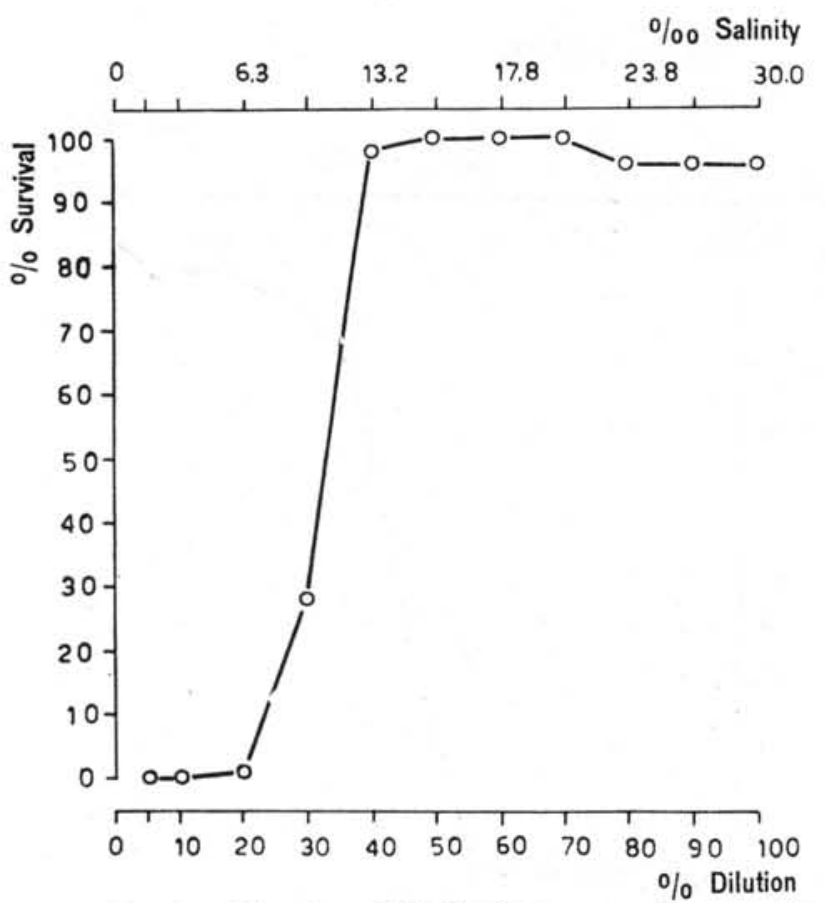

Acartia lilljeborgi aclimatized to $30 \%$

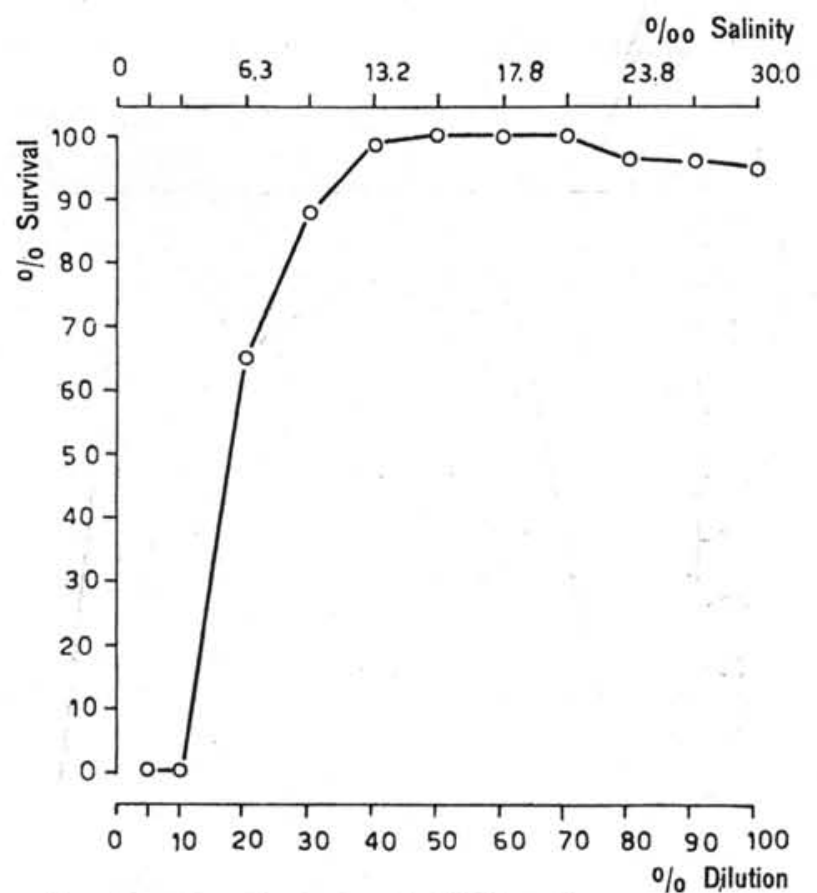

Fig. 6 - Salinity tolerances of non acclimatized and acclimatized Acartia lilljeborgi.

TABLE II - The lethal salinities, mortality, field and experimental temperature, for the species studied

\begin{tabular}{|c|c|c|c|c|c|c|}
\hline SPECIES & STAGES & $\begin{array}{l}\text { Lethal } \\
\text { salinity } \\
(\% \%)\end{array}$ & $\begin{array}{l}\text { Dilution } \\
(\%)\end{array}$ & \multicolumn{2}{|c|}{$\begin{array}{l}\text { Range of salinity/dilution } \\
\text { causing mortality }\end{array}$} & $\begin{array}{c}\text { Field } \\
\text { temperature } \\
{ }^{\circ} \mathrm{C} \quad\left(^{*}\right)\end{array}$ \\
\hline Pseudodiaptomus acutus & $\begin{array}{l}\text { adult } \\
\text { females }\end{array}$ & 23.8 & 80 & $20.9-30.0 \%$ & $70 \%-100 \%$ & 26.2 \\
\hline Temora stylifera & $\begin{array}{l}\text { mainly } \\
\text { adult } \\
\text { females }\end{array}$ & 15.1 & 50 & $1.6-20.9 \%$ & $5 \%-70 \%$ & 26.8 \\
\hline Centropages furcatus & $\begin{array}{l}\text { adult } \\
\text { females }\end{array}$ & 13.1 & 40 & $1.6-13.2 \%$ & $5 \%-40 \%$ & 26.6 \\
\hline Euterpina acutifrons & $\begin{array}{l}\text { adult } \\
\text { females }\end{array}$ & 8.8 & 30 & $1.6-13.2^{\circ} / \mathrm{oo}$ & $5 \%-40 \%$ & 26.0 \\
\hline Acartia lilljeborgi & $\begin{array}{l}\text { adult } \\
\text { females }\end{array}$ & 8.8 & 30 & $1.6-8.8 \%$ & $5 \%-30 \%$ & 26.4 \\
\hline Oithona ovalis & $\begin{array}{l}\text { adult } \\
\text { females }\end{array}$ & $\begin{array}{l}6.3 \\
30\end{array}$ & $\begin{array}{r}20 \\
100\end{array}$ & $\begin{array}{c}1.6-6.3 \% \\
30 \%\end{array}$ & $\begin{array}{c}5 \%-20 \% \\
100 \%\end{array}$ & 26.2 \\
\hline Decapod Larvae & Zoea & - & - & - & - & 26.2 \\
\hline
\end{tabular}

(*) Experimental temperature: $25 \pm 1^{\circ} \mathrm{C}$. 
TABLE III - Magnitude of salinity change, and maximum rate of salinity change per hour at three stations

\begin{tabular}{|c|c|c|c|}
\hline STATION & $\begin{array}{l}\text { DEPTH } \\
(\mathrm{m})\end{array}$ & $\begin{array}{l}\text { Magnitude of salinity change during } \\
6 \text { hours }\end{array}$ & $\begin{array}{l}\text { Maximum rate of salinity } \\
\text { change } / \mathrm{h}\end{array}$ \\
\hline \multirow{2}{*}{$\begin{array}{l}\quad \text { I } \\
\text { Baguassú } \\
\text { River }\end{array}$} & 0 & $7.43^{\circ} \%$ o $-20.65 \%$ & $3.13 \%$ o \\
\hline & 5 & $7.97 \%-21.8 \%$ & $3.01 \%$ \\
\hline \multirow{2}{*}{$\begin{array}{c}\text { II } \\
\text { Argolāo }\end{array}$} & 0 & $17.07 \%-28.43 \%$ & $2.14 \%$ \\
\hline & 5 & $18.84 \%-31.43^{\circ} \%$ & $6.85 \%$ \\
\hline \multirow[b]{2}{*}{ Trincheira } & 0 & $18.60^{\circ} / \mathrm{oo}-31.85^{\circ} \%$ o & $4.71 \%$ \\
\hline & 5 & $24.61 \%-32.23 \%$ & $2.30 \%$ \\
\hline
\end{tabular}

TABLE IV - Station I - Baguassu River - The percentage of species, according to depth and tide, the corresponding salinities and light penetration, at station I

\begin{tabular}{|c|c|c|c|c|c|}
\hline SPECIES & $\begin{array}{l}\text { Species } \\
(\%)\end{array}$ & $\begin{array}{l}\text { Depth } \\
\text { (m) }\end{array}$ & $\begin{array}{l}\text { Salinity } \\
\left(\% / 0_{0}\right)\end{array}$ & Tide & $\begin{array}{l}10 \% \text { level light } \\
\text { penetration }\end{array}$ \\
\hline Pseudodiaptomus acutus & 94.6 & 0 & 7.43 & \multirow{6}{*}{ Low } & \multirow{6}{*}{$0.70 \mathrm{~m}$} \\
\hline Acartia lilljeborgi & 5.4 & & & & \\
\hline Oithona ovalis & - & & & & \\
\hline Pseudodiaptomus acutus & 98.2 & & & & \\
\hline Acartia lilljeborgi & 0.9 & 3.0 & 7.84 & & \\
\hline Oithona ovalis & 0.9 & & & & \\
\hline Pseudodiaptomus acutus & 7.6 & & & \multirow{6}{*}{ High } & \multirow{6}{*}{$1.30 \mathrm{~m}$} \\
\hline Acartia lilljeborgi & 88.6 & 0 & 20.65 & & \\
\hline Oithona ovalis & 3.3 & & & & \\
\hline Pseudodiaptomus acutus & 82.2 & & & & \\
\hline Acartia lilljeborgi & 15.4 & 3.0 & 21.81 & & \\
\hline Oithona ovalis & 0.4 & & & & \\
\hline
\end{tabular}

\section{DISCUSSION}

These short-term experiments are of interest in this type of environment once short exposure to diluted of full strengh sea water (i.e. water of salinity $30 \%$ in this case) are of considerable importance in the survival of the different species.

The effect of variation of salinity on the metabolism of the species studied can influence their survival as demonstrated by LANCE (1964) for some species of Acartia and Ranade (1957) for Tigriopus fulvus.
Although the results for laboratory experiments cannot be compared directly with the field studies, as Bassindale (1943) pointed out, a certain indication can be given if the known distribution of the species is checked with the experimental results.

Euterpina acutifrons is found in estuaries as well as in coastal waters but its greatest numbers were found in coastal waters - BJöRNBERG (1963), TEIXEIRA et al. (1965) from $14 \%$ to $35 \%$.

Oithona ovalis is characteristic of inshore waters and not found in coastal waters. It was found at 
Cananéia in great numbers - TeIXeIRA et al. (1965) in inshore waters.

Sewell (1934) indicates that certain species of Acartia can migrate into brackish or fresh water. Acartia lilljeborgi is found in coastal waters, where it is sometimes the dominant copepod, but penetrates successfully in estuaries. Its ability to acclimatize to lower salinities probably helps on its sucess in inshore waters.

The two marine genera Centropages and Temora have euryhaline tendencies - BAYLY, 1965; JEFFrIES (1962) recorded these two genera in Raritan Bay at salinities of $21 \%$. The present results on salinity tolerance agree well with the known distribution for Centropages furcatus and Temora stylifera. They are typical of coastal or shelf water, being found in inshore waters only as astray visitors.

Pseudodiaptomus acutus is abundant in estuarine waters and according to BJöRnBERg (1963), TEIXEIRA, TUNDISI \& KUTNER (1965) is eurythermic and eury. haline. This species was found in greatest numbers in the inner parts of the lagoon where the average salinity is relatively low. Kato (1966).

Some experiments with Pseudodiaptomus acutus demonstrated that the animals collect at the bottom of a dish, away from the light when they are subjected to diffuse or direct light from above.

Sampling made at station I (Baguassu River) simultaneously with measurements on light penetration and salinity demonstrated that as salinity increases the greatest number of animals is found at depth (Table IV). An effect of temperature seems improbable, once a difference of not more than $2^{\circ} \mathrm{C}$ occurs in the water column, in this station.

Thus it seems probably that as the light conditions change with the tide this species migrates vertically to the deep layers and would drift alternately upstream and downstream. Therefore the combined effect of a negative response to light, and the tolerances to a wide range of salinities, would assist in the maintenance of this species at certain positions in the inner parts of the lagoon.

This type of mechanism was demonstrated by Barlow (1955) for A. tonsa copepodids.

Bousfield (1955) pointed out that in the Miramichee estuary the distribution of barnacles is influenced by seaward movements of mixed and salt water and the landward counter current associated with it and Cronin, Daiber \& Hulbert (1962) have made also the same suggestion for the maintenance of certain planktonic animals in the Delaware River.

The present results give a reasonable indication of this probability.

These data would thus suggest that salinity is a limiting factor on the distribution and succession or some planktonic species in the inshore waters and in limiting the coastal species in their penetration in these waters. However, studies on the tolerances to salinity of the different stages of life history as well as studies on growth and reproduction would have to be made to confirm this probability; frequently salinity tolerance ranges of adults of a species differ considerably from those of larvae and this may limit or not species distribution.

Other factors might be of importance in the distribution of species in this area. Recent work (TEIXEIRA et al., 1967; 1967 unpublished results) on the study of the distribution of different size fractions of the phytoplankton, demonstrated that in inshore waters the fraction smaller than $65 \mu$ was responsible for an average of $61.0 \%$ of the total C-14 uptake.

Thus food selectivity by the herbivore zooplankton might be also of importance in its distribution in inshore waters.

\section{R ES U MO}

A tolerância à salinidade e temperatura de seis espécies de copépodos planctônicos (fêmeas adultas) foi estudada na região lagunar de Cananéia, a $25^{\circ}$ latitute sul.

Os resultados demonstraram que a tolerância à salinidade das espécies estudadas, apresenta grandes variações.

Com base nesses experimentos, a seguinte ordem de tolerância à salinidade (em temperatura próxima à do campo $\pm 1^{\circ} \mathrm{C}$ ) pode ser dada para as espécies estudadas:

Pseudodiaptomus acutus $>$ Euterpina acutifrons $>$ Acartia lilljeborgi $>$ Oithona ovalis > Centropages furcatus $>$ Temora stylifera.

Um mecanismo para a manutenção de Pseudodiaptomus acutus em certas regiōes da área estudada é proposto, baseado nas respostas à luz e diferentes salinidades.

\section{R E FER ENCES}

BARLOW, J. P.

1955. Physical and biological processes determining the distribution of zooplankton in a tidal estuary. Biol. Bull. mar. biol. Lab., Woods Hole, vol. 109, p. 211-225.

BARNES, H.

1953. The effects of lowered salinity on some barnacle nauplii. J. Anim. Ecol., vol. 22, p. $328-330$.

BARNETT, R. R. O.

1959. The ecology of harpacticoids on a mudflat with special reference to Platychelipus. Ph. D. Thesis, University of Southampton.

Bassindale, E.

1943. A comparison of the varying salinity conditions of the Tees and Severn estuaries. J. Anim. Ecol., vol. 12, p. 1-10.

BAYLY, I. E. A.

1965. Ecological studies on the planktonic copepoda of the Brisbane River estuary with special reference to Gladioferens 
pectinatus (Brady) (Calanoida). Aust. J. mar. Freshwat. Res., vol. 16, n. ${ }^{\circ} 3$, p. $315-350$.

BJÖRNBERG, T. K. S.

1963. On the marine free-living copepods off

Brazil. Bolm Inst. oceanogr., S Paulo, vol. 13, n. $^{\circ} 1$, p. 3-142.

Bousfield, E. L.

1955. Ecological control of the occurrence of barnacles in the Miramichi estuary. Bull. natn. Mus. Can., vol. 137, 69 p.

Cronin, L. E., Daiber, J. C. \& Hulbert, E. M.

1962. Quantitative seasonal aspects of zooplankton in the Delaware River estuary. Chesapeake Sci., vol. 3, p. 63-93.

GUNTER, G.

1961. Some relations of estuarine organisms to salinity. Limnol. Oceanogr., vol. 6 , p. $182-190$.

HANSEN, K. \& ANDERSON, K. P.

1962. Sampling the smaller zooplankton. Rapp. P.-v. Réun. Cons. perm. int. Explor. Mer, vol. 153 , p. $39-47$.

HARVEY, H. W.

1955. The chemistry and fertility of sea water. Cambridge, University Press, 219 p.

HOPPER, F.

1960. The resistance of marine zooplankton of the Caribbean and South Atlantic to changes in salinity. Limnol. Oceanogr., vol. 5 , p. $43-47$.

JEFFRIES, H. P.

1962a. Copepod indicator species in estuaries. Ecology, vol. 43, n. ${ }^{\circ}$, p. $730-732$.

1962b. Succession of two Acartia species in estuarines. Limnol. Oceanogr., vol. 7, p. 354-364.

KATO, K.

1966. Chemical investigations on the hydrographical system of Cananéia lagoon. Bolm Inst. oceanogr. S Paulo, vol. 15, n. ${ }^{\circ} 1$, p. 1-12.

KETCHUM, B. H.

1954. Relation between circulation and planktonic organisms in estuaries. Ecology, vol. 35 , p. $191-200$.
KINNE, O.

1963.

The effects of temperature and salinity on marine and brackish water animals. I. Temperature. Oceanogr. mar. Biol., A. Rev., vol. 1, p. 301-340.

LANCE, J.

1962. Effects of water of reduced salinity on the vertical migration of zooplankton. J. mar. biol. Ass. U. K., vol. 42, p. 131-154 .

1964. The salinity tolerances of some estuarine planktonic crustaceans. Biol. Bull. mar. biol. Lab., Woods Hole, vol. 127, n. ${ }^{\circ} 1$, p. 108 .

Marshall, S. M., Nichols, G. \& OrR, A. P.

1935. On the biology of Calanus finmarchicus. VI. Oxygen consumption in relation to environmental conditions. J. mar. biol. Ass. U. K., vol. 20, p. 1-27.

RANADE, M. R. 1957.

Observations on the resistance of $T i$ griopus fulvus (Fischer) to changes in temperature and salinity. J. mar. biol. Ass. U.K., vol. 36, p. 116-119.

Sewell, R. B. S,

1934. A study of the fauna of the Salt Lake, Calcutta. Rec. Indian Mus., vol. 36, p. $45-121$

Teixeira, C. \& Kutner, M. B.

1962. Plankton studies in a mangrove environment. I. First assessment of standing-stock and principal ecological factors. Bolm Inst. oceanogr. S Paulo, vol. 12, n. 3, p. 101-124.

Teixeira, C., Tundisi, J. \& Kutner, M. B.

1965. Plankton studies in a mangrove environment. II. The standing-stock and some ecological factors. Bolm Inst. oceanogr. S Paulo, vol. 14, n. $.^{\circ} 1, \mathrm{p}$. 13-42.

Teixeira, C., Tundisi, J. \& Santoro Ycaza, J.

1967. Plankton studies in a mangrove environment. IV. Size fractionation of the phytoplankton. Bolm Inst. oceanogr. S Paulo, vol. 17 , n. ${ }^{\circ} 1$, p. $39-42$.

VANNUCCI, M.

1957. On Brazilian Hydromedusae and their distribution in relation to different water masses. Bolm Inst. oceanogr. S Paulo, vol. 8, n. ${ }^{\circ} 1 / 2$, p. 23-109. 